Saudi Journal of Medical and Pharmaceutical Sciences

Abbreviated Key Title: Saudi J Med Pharm Sci

ISSN 2413-4929 (Print) |ISSN 2413-4910 (Online)

Scholars Middle East Publishers, Dubai, United Arab Emirates

Journal homepage: https://saudijournals.com/sjmps

Original Research Article

\title{
Preliminary Phytochemical Analysis and TLC Fingerprinting of Desmostachya bipinnata
}

\author{
Dr. Ranjana Jai Singh ${ }^{1 *}$, Dr. Pooja Nautiyal ${ }^{2}$, Amit Kumar $^{3}$ and Jitender K Malik ${ }^{3}$ \\ ${ }^{1}$ Om Ayurvedic Medical College Hospital and Research Center-Roorkee (Haridwar) \\ ${ }^{2}$ Smt.Manjira Devi Ayurvedic Medical College and Hospital-Uttarkashi-India \\ ${ }^{3}$ Smt.Manjira Devi Shikshan and Prashiksan Institute Hitanu Dhanari- Uttarkashi-India
}

\author{
DOI: $10.36348 /$ sjmps.2020.v06i03.007 \\ | Received: 12.03.2020 | Accepted: 20.03.2020 | Published: 27.03.2020 \\ *Corresponding author: Dr. Ranjana Jai Singh
}

\section{Abstract}

The nature has provided an entire warehouse of remedies to cure ailments of mankind. About 80 per cent of the world's population depends partially or wholly on traditional medicine for its primary health care needs. Herbal medicines as the key remedy in traditional medical system have been used in medical practice for past era and have made a great involvement to maintain human health. Thus Pharmacognostical study appears to be of enormous value in identification of commercial samples of the market to find their authenticity and establishing identity of adulterant or substituent. In addition lack of standardization, dishonest commercial practice of adulterating and substituting the genuine herbal drugs are posing great obstacle in popularizing the time-tested herbal-based traditional medicines. The present study was focused on preliminary pharmacognostic and phytochemical investigations for determining and establishing the identity, purity and quality of the plants. The plant was subjected to determination of various physicochemical parameters including ash values (total ash, water soluble ash) and extractive values (alcohol soluble extractive, water soluble extractive). The powdered crude drug was extracted successively with various solvents with increasing polarity and further the extracts were subjected to phytochemical screening for the identification of various phytoconstituents. The study of heavy metal analysis, total bacterial count \& test for Aflatoxins studies was also carried out as WHO guidelines. More over the fingerprint profile of Desmostachya bipinnata was established using thin layer chromatography(TLC) methods. The results of the TLC profiling of the extract confirm about the presence of various phytochemicals.

Keywords: of Desmostachya bipinnata,Microscopy, Phytochemical investigations \& TLC profiling.

Copyright @ 2020: This is an open-access article distributed under the terms of the Creative Commons Attribution license which permits unrestricted use, distribution, and reproduction in any medium for non-commercial use (NonCommercial, or CC-BY-NC) provided the original author and source are credited.

\section{INTRODUCTION}

An herbal drug constitutes a most important part in all traditional systems of medicine. There are approximately 1250 Indian medicinal plants which are used in formulating therapeutic preparations according to Ayurvedic and other traditional systems of medicine. Plants endow with varieties of resources that contribute to the fundamental need of food, clothing and shelter[1]. Desmostachya bipinnata (Linn.) belongs to the family, Poaceae (Graminaea). It is well-known as Sacrificial Grass or Saved Gram in English. The plant is known for holy purpose as well as medicinally uses. It is famous as Tharuppai and its kudineer is prescribed for any type of disorder, fevers, itching and diuretic problems in Siddha literatures. It is valuable for curing urinary tract diseases and excessive vaginal discharges [2]. Many secondary metabolites such as scopoletine, umbelliferone, sugars, amino acids, carbohydrates are reported in the plant. Desmostachya bipinnata is traditionally known as Kusha grasses that are form vital ingredient in various Vedic sacrifices (Yagnas) and rituals. They are found along river beds and plains throughout India and are well known for their medicinal properties as supported by traditional Ayurvedic scriptures and are a vital component in traditional medicinal formulations such as Tripanchamool, Kusadya-ghrita and Kusa blecha, etc. to treat many disorders such as dysentery, diuresis, jaundice, skin infections etc[3]. 


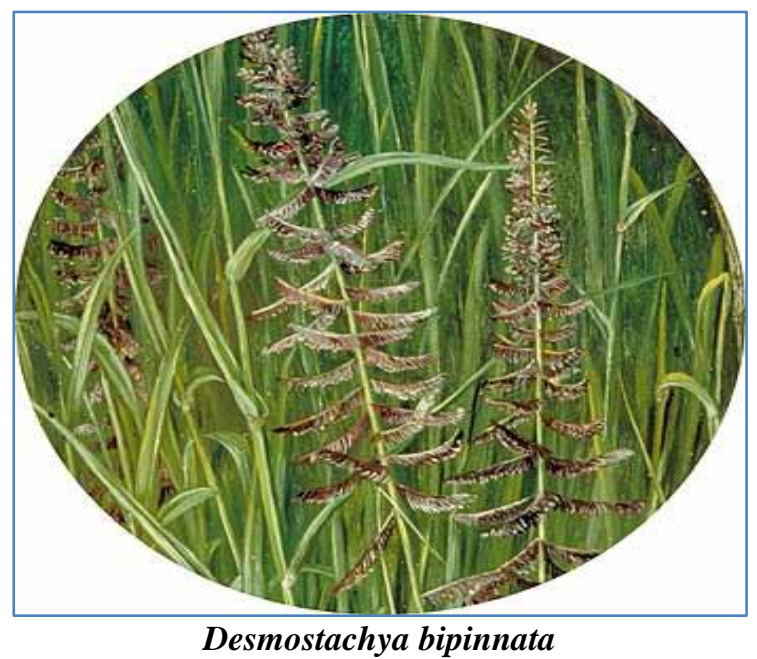

\section{Materials ANd Methods Collection}

The sample of Desmostachya bipinnata was collected from Haridwar, State - Uttrakhand. The sample of Desmostachya bipinnata was collected by scholar under the guidance of Supervisor after identifying the source of plant as per standard description.

\section{Date of Collection}

Desmostachya bipinnata-5/12/2015 (Haridwar)

\section{Authentication}

The plant was authentication was done Botanical Survey of India (BSI), Dehradun.

\section{Microscopic study}

Microscopic study of crude drugs is another aid of Pharmacognosy which can be helpful in the process of standardization of medicinal plants. This study can be helpful in identifying genuine drug by their known histological characters through Transverse section (T.S.) or Longitudinal Section (L.S.) or Radial Longitudinal Section (R.L.S.) or Tangential Longitudinal Section (T.L.S.) and Powder microscopy which can help in evaluation of different constituents by using different staining reagents. Specimens were soaked in water or other sovents depending upon the hardness of the sample and transverse sections were taken using sharp razor blades. Few microscopic sections were cut by Microtome sectioning. Numerous temporary and permanent mounts of the microscopical sections of the specimen were made and examined microscopically. Different staining reagents were applied on transverse sections so as to differentiate between different cell wall components.
Preliminary physiochemical screening of plant extracts[4-8]

\section{Determination of solvent extractive values}

Determination of water soluble extractive value: $5 \mathrm{~g}$ of the air-dried drug, coarsely powdered were macerated with $100 \mathrm{ml}$ of water in closed flask for 24 hours, shaking frequently during the first 6 hours and allow standing for 18 hours. It was filtered rapidly taking precaution against loss of water, then the filtrate was evaporated $25 \mathrm{ml}$ of the filtrate to dryness in a tared flat-bottomed shallow dish, and dried at $105^{\circ} \mathrm{C}$ then weighed. The percentage of water-soluble extractive with reference to the air dried was calculated.

Determination of alcohol soluble extractive value: $5 \mathrm{gm}$ of the air dried and coarsely powdered drug was macerated with $100 \mathrm{ml}$ of ethanol of the specific strength in a closed flask for 24 hours, shaking frequently during the first 6 hours and allow standing for 18 hours. There after filter rapidly taking precaution against loss of ethanol. Evaporate $25 \mathrm{ml}$ of the filtrate to dryness in a tared flat bottomed shallow dish, dry at $105^{\circ} \mathrm{c}$ and weigh. The percentage of ethanol soluble extractive with reference to the air dried drug has to be calculated.

Determination of moisture content: Moisture is an inevitable component of crude drugs, which must be eliminated as far as practicable. Method of determination of moisture content include the loss on drying, the test for loss on drying determines both water and volatile matter in the crude drug. It can be carried out either by heating at $100^{\circ} \mathrm{C}-105^{\circ} \mathrm{C}$ or in a dessicator over phosphorous pentoxide under atmospheric or reduced pressure at room temperature for specific period of time.

Ash value: Ash value is helpful in determining the quality and purity of a crude drug, especially in the powdered form. On incineration, crude drugs normally leave an ash usually consisting of carbonates, phosphates and silicates of sodium, potassium, calcium and magnesium. The total ash of a crude drug reflects the care taken in its preparation. A higher limit of acidinsoluble ash is imposed, especially in case where silica may be present or when the calcium oxalate content of the drug is very high.

Total ash value: Weighed accurately about 2 to $3 \mathrm{~g}$ of the powdered drug in a tared silica crucible. Incinerated at a temperature not exceeding $450{ }^{\circ} \mathrm{C}$ for 4 $\mathrm{hr}$, until free from carbon, cooled and weighed. The percentage of ash with reference to air-dried was calculated following formula.

$$
\% \text { Total ash value }=\frac{\text { Wt. of total ash }}{\text { Wt. of crude drugs }} \times 100
$$


Water soluble ash value: Boiled the ash with $25 \mathrm{ml}$ of water. Filtered and collected the insoluble matter on an ash less filter paper, washed with hot water and ignited in a tared crucible at a temperature not exceeding $450{ }^{0} \mathrm{C}$ for $4 \mathrm{hr}$. Cooled in a desiccator and weighed. Substrate the weight of insoluble matter from the total weight of ash. The difference in weight represented weight of water soluble ash. Calculated the percentage of water soluble ash with reference to the air- dried drug by using the following formula.

\section{$\%$ Water soluble ash value $=\quad$ Wt. of total ash-Wt.of water insoluble ash $\times 100$ Wt. of crude drug taken}

Acid insoluble ash value: Boiled the ash for 5 min with $25 \mathrm{ml}$ of $2 \mathrm{M}$ HCL. Filtered and collected the insoluble matter on an ash less filter paper, washed with hot water and ignited in a tared crucible at a

\section{$\%$ Acid insoluble ash value $=$}

\section{Preliminary qualitative test}

The various extract of Desmostachya bipinnata was subjected to preliminary qualitative phytochemical investigation. The various tests and reagent used are given below.

\section{Alkaloids \\ Preparation of test solution: The test solution was prepared by dissolving extracts in the dilute hydrochloric acid. \\ Mayer' test: The acidic test solution with Mayer's reagent (Potassium Mercuric iodide) gave cream colored precipitate.}

Hager's test: The acidic test solution with Hager's reagent (Saturated picric acid solution) gave yellow precipitate.

Dragendorff's test: The acidic solution with Dragendorff's reagent (Potassium bismuth iodide) showed reddish brown precipitate.

Wagner's test: The acidic test solution treated with Wagner's reagent (Iodine in potassium iodide) gave brown precipitate.

Tannic acid test: The acidic test solution treated with Tannic acid gave buff colour precipitate.

Picrolonic acid test: Alkaloids gave yellow colour precipitate with picrolonic acid.

\section{Amino acid}

Millon'test: To the test solution add about $2 \mathrm{ml}$ of millon's reagent white precipitate indicates presence of amino acid. temperature not exceeding $450{ }^{\circ} \mathrm{C}$ for $4 \mathrm{~h}$. cooled in a desiccator and weighed. Calculated the percentage of acid insoluble ash with reference to the air -dried drug was calculated by using following formula,

\section{Wt. of acid insoluble ash $\quad \times 100$ Wt. of crude drug taken}

Ninhydrine test: To the test solution add Ninhydrine solution, boil, violet colour indicates presence of amino acid.

\section{Carbohydrates}

Preparation of test solution: The test solution was prepared by dissolving the test extracts with water. Then it was hydrolyzed with 1 volume of $1 \mathrm{~N}-\mathrm{HCL}$ and subjected to following chemical test.

Molisch's test: Test solution with few drops of Molisch's reagent and $2 \mathrm{ml}$ of conc. $\mathrm{H}_{2} \mathrm{So}_{4}$ added slowly from the sides of the test tubes. It showed a purple ring at the junction of two liquids.

Barfoed's test: $1 \mathrm{ml}$ of test solution is heated with $1 \mathrm{ml}$ of Barfoed, s reagent on water bath, if red cupric oxide is formed, monosaccharide is present. Disaccharides on prolong heating (about $10 \mathrm{~min}$.) may also cause reduction, owing to partial hydrolysis to monosaccharide.

Benedict's test: Test solution treated with Benedict' reagent and after boiling on water bath, it showed reddish brown precipitate.

Fehling's test: The test solution when heated with equal volume of Fehling's A and B solution, gave orange red precipitate, indicating the presence of reducing sugars

Flavonoids: The flavonoids are all structurally derived from the parent substance called flavones. The flavonoids occur in the free from as well as bound to sugars as glycosides. For this reason, when analyzing flavonoids it is usually better to examine the flavonoids in hydrolyzed plant extracts. 
Preparation of test solution: To a small amount of extract added equal volume of $2 \mathrm{M}$ HCL and heated in a test tube for 30 to $40 \mathrm{~min}$ at $100^{\circ} \mathrm{C}$.The cooled extract was filtered, and extracted with ethyl acetate The ethyl acetate was concentrated to dryness, and used to test for flavonoids.

Shinoda test: Test solution with few fragments of magnesium ribbon and conc. HCL showed pink to magenta red colour. To a small quantity of test solution when lead acetate solution was added, it formed yellow colored precipitate.

Alkaline reagent test: Test solution when treated with sodium hydroxide solution showed increase in the intensity of yellow colour, which becomes colorless on addition of few drops of dilute acid.

\section{Glycosides}

Preparation of test solution: The test solution was prepared by dissolving extract in the alcohol or hydro- alcoholic solution.

\section{Test for Cardiac glycosides}

Kedde' test: Add one drop of $90 \%$ alcohol and 2 drops of $2 \%$ 3, 5- dinitro benzoic acid in 90\% alcohol. Make alkaline with $20 \%$ sodium hydroxide solution, purple colour is produced. The colour reaction with 3,5-dinitro benzoic acid depends on the presence of $\alpha, \beta$-unsaturated lactones in the aglycone.

Baljet's test: The test solution treated with sodium picrate gave yellow to orange colour. Raymond's test: Test solution treated with hot methanolic alkali, violet colour is produced. Bromine water test: Test solution dissolve in bromine water give yellow precipitate.

Keller-killani test for digitoxose: The test solution treated with few drops of Fecl3 solution and mixed, then $\mathrm{H}_{2} \mathrm{So}_{4}$ containing Fecl3 solution was added, it formed two layers. Lower layer reddish brown, upper layer turns bluish green.

Legal's test: Test solution when treated with pyridine (made alkaline by adding sodium nitroprusside solution) gave pink to red colour.

\section{Test for anthraquinone glycosides}

Borntrager's test: Boiled powdered drug with $5 \mathrm{ml}$ of $10 \%$ sulphuric acid for five minutes. Filtered while hot, cooled the filtrate shaken gently with equal volume of benzene. Benzene layer was separated and then treated with half of its volume solution ammonia (10\%). Allowed to separate it. The ammonical layer acquired rose pink colour due to presence of anthraquinones.

\section{Proteins}

Preparation of test solution: The test solution was prepared by dissolving the extract in water.

Millon's test: Test solution was treated with millon's reagent and heated on a water bath. The proteins were stained red

Biuret test: Test solution was treated with $40 \%$ sodium hydroxide and dilute copper sulphate solution gave blue colour.

Xanthoproteic test: Test solution was treated with conc. $\mathrm{HNO}_{3}$ and boiled which gave yellow precipitate.

Modified Borntrager's test: C-glycosides of anthraquinones require more drastic conditions for hydrolysis. Hydrolysis of the drug was carried out with $5 \mathrm{ml}$ of dilute of HCL and $5 \mathrm{ml}$ of $5 \%$ solution of $\mathrm{Fecl}_{3}$. For hydrolyzed extract procedure was carried out as described under Borntrager's test.

\section{Test for steroids}

Preparation of test extract solution: The extract was refluxed separately with alcoholic solution of potassium hydroxide till complete saponification. The saponified extract was diluted with water and unsaponificable matter was extracted with diethyl ether. The ethereal extract was evaporated and the residue (saponificable matter) was subjected to the following test by dissolving the residue in the chloroform.

Salkowski test: To the test extract solution add few drops of conc. $\mathrm{H}_{2} \mathrm{SO}_{4}$ shaken and allowed to stand, lower layer turned red indicating the presence of steroids.

Libermann - Burchard test: The test solution treated with few drops of acetic anhydride and mixed, when conc. $\mathrm{H}_{2} \mathrm{SO}_{4}$ was added from the sides of the test tubes, it showed a brown ring at the junction of the two layers and the upper layers turned green. Added few drops of concentrated $\mathrm{H}_{2} \mathrm{SO}_{4}$. Blue colour appeared.

Sulphur test: Sulphur test when added in to the test solution, it sank it.

\section{Tannins and phenol compound}

To 2-3 $\mathrm{ml}$ of alcoholic or aqueous extract, added few drops of following reagents.

$5 \%$ Fecl $_{3}$ solution: Deep blue- black colour.

Lead acetate solution: White precipitate.

Bromine water: Discoloration of bromine water

Acetic acid solution: Red colour solution. 
Dilute iodine solution: Transient red colour

One drop of $\mathrm{NH}_{4} \mathrm{OH}$, excess $10 \% \mathrm{AGNO}_{3}$ solution. Heated for $20 \mathrm{~min}$ in boiling water bath. White precipitate was observed, then dark silver mirror deposited on wall of test tube.

\section{Triterpenoids}

Preparation of test extract solution: The test extract solution was prepared by dissolving extract in the chloroform.

Salkowski test: Few drops of concentrated sulphuric acid were added to the test solution, shaken and on standing lower layer turned golden yellow.

\section{Microbiological determination tests [9-10]}

Total viable aerobic count (TVC): Detection of the anti-bacterial activity of the test drug, the total viable aerobic count (TVC) of the test drug was carried out, as specified in the test procedure, using plate count. Pre-treatment of the test drug Depending on the nature of the herbal drug sample used, it was dissolved using a suitable method and any antimicrobial property present in the sample was eliminated by dilution or neutralization. Buffered Sodium Chloride-Peptone Solution, $\mathrm{pH} 7.0$ was used to dilute the test sample.

\section{Plate count for bacteria and fungi}

For bacteria: $1 \mathrm{ml}$ of the pretreated test sample was added to about $15 \mathrm{ml}$ of the liquefied caseinsoybean digest agar in a petridish of $90 \mathrm{~mm}$ diameter at a temperature not exceeding $450 \mathrm{C}$. Alternatively the test sample was spread on the surface of the solidified medium. Two dishes were prepared with the same dilution, they were inverted and incubated at 30-350C for 48-72 h, unless a more reliable count was obtained in a short period of time. The number of colonies so formed was counted and the results were calculated using the plates with the largest number of colonies, up to a maximum of 300 .

For fungi: $1 \mathrm{ml}$ of the pretreated test sample was added to about $15 \mathrm{ml}$ of the liquefied Sabered glucose agar with antibiotics in a petridish of $90 \mathrm{~mm}$ diameter at a temperature not exceeding $45^{\circ} \mathrm{C}$. Alternatively the test sample was spread on the surface of the solidified medium. Two dishes were prepared with the same dilution; they were inverted and incubated at $20-250 \mathrm{C}$ for 5 days, unless a more reliable count was obtained in a short period of time. The number of colonies so formed was counted and the results were calculated using the plates with not more than 100 colonies.

\section{Aflatoxins}

The test for determination of the aflatoxins was carried out using LCMS-Ms.
TLC analysis for different Phytochemicals

T.L.C. plate coated with $0.25 \mathrm{~mm}$ layer of silica gel $\mathrm{GF}_{254}$ with fluorescent indicator, (Mercks) were used. (Each plate dimension is $10 \mathrm{~cm}$ long and $2 \mathrm{~cm}$ width).

\section{Activation of pre-coated Silica gel $\mathbf{G 6 0 F}_{254}$ Dry in hot oven at $105^{\circ} \mathrm{C}$ for one to two} hour.

\section{Solvent system: Toluene, Ethyl Acetate (7:3)}

Sample: Alcoholic Extract of test sample

Visualization: $p$-Anisaldehyde - sulfuric acid Reagent.

\section{RESULT AND DISCUSSION}

In Vedic texts Trinpanchmoola drugs like Kush is called ideal grass in Hindu religion, and described as Asan for Indra. The roots are cooling, diuretic, astringent and galactogogue and are useful inn asthma, jaundice, stimulant, acrid and aphrodisiac and useful in dysentery, menorrhagia, jaundice, asthma and skin eruption. The collected drug were studied organoleptically with naked eye \& magnifying lens, with the help of different Organoleptic features i.e. Colour, Odour, Taste, and Appearance were recorded(table 1). T.S of root showing sclerenchymatous cells,endodermis, metaxylem and phloem. The powder microscopic characteristics study revealed the presence of tannins, calcium sulphate ,cutin \& lignins (table 2). Various physiochemical parameters were studied and result was tabulated in the table 3. The extractive value was found to be $11.21 \%$ w/w \% (Alcohol Extractive Value) and 16.89\% w/w (Aqueous Extractive Value).The phytochemical screening(table 4) revealed the presence of the various phytochemical in order Aqueous extract $>$ Alcoholic extract > Pet.ether extract. As per WHO guideline of quality control of Herbal plants, the heavy metals analysis, total bacterial count and alfatoxins detection studies were carried out. The result was tabulated in the table 5-7. In Chromatographic study, TLC (table 8) study showed the presence of phenol, sugars, steroids and terpenes nature of chemical constituents in all genuine samples and $\mathrm{R}_{\mathrm{f}}$ value of Desmostachya bipinnata were $0.15,0.78,0.81 .0 .87$.

\section{Conclusion}

The present study deals with macroscopic, powder microscopic, phytochemical analysis and TLC fingerprinting. These studied will make available referentially information for correct identification and for standardization. This study also gives support to in the assessing of adulteration and substitution in market sample of the plant. 


\begin{tabular}{|c|c|}
\hline Characters & Desmostachya bipinnata \\
\hline Appearance & Tufted grass with a thick scaly root stock \\
\hline Colour & Pale brown \\
\hline Odour & Odourless \\
\hline Taste & Slight bitter \\
\hline
\end{tabular}

Table-2: Powder Microscopy

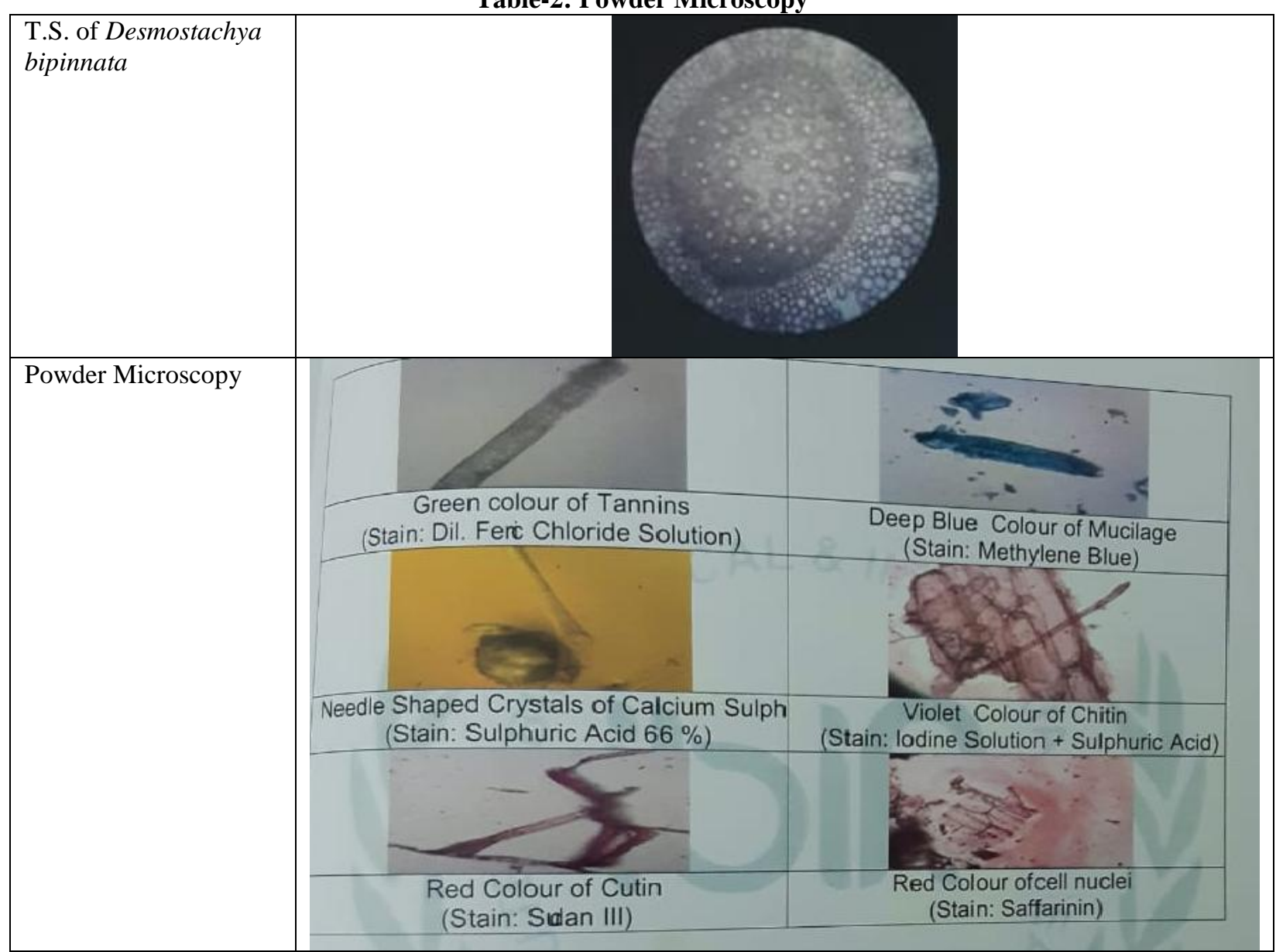

Table-3: Physiochemical study of Parameters

\begin{tabular}{|c|c|c|}
\hline S.No & Tests & Desmostachya bipinnata \\
\hline 1 & Moisture content & $8.70 \% \mathrm{w} / \mathrm{w}$ \\
\hline 2 & $\mathrm{pH}$ & 7.97 \\
\hline 3 & Alcohol Extractive Value & $11.21 \% \mathrm{w} / \mathrm{w}$ \\
\hline 4 & Aqueous Extractive Value & $16.89 \% \mathrm{w} / \mathrm{w}$ \\
\hline 5. & Pet.ether Extractive value & $3.74 \% \mathrm{w} / \mathrm{w}$ \\
\hline 6 & Foreign matter & $1.14 \% \mathrm{w} / \mathrm{w}$ \\
\hline 7 & Total Ash & $6.82 \% \mathrm{w} / \mathrm{w}$ \\
\hline 8 & Acid Insoluble Ash & $2.45 \% \mathrm{w} / \mathrm{w}$ \\
\hline 9 & Water Soluble Ash & $3.13 \% \mathrm{w} / \mathrm{w}$ \\
\hline
\end{tabular}


Table-4: Results of preliminary phytochemical analysis

\begin{tabular}{|c|c|c|c|c|}
\hline \multirow[t]{2}{*}{ Sr. No. } & \multirow[t]{2}{*}{ Name of the Test } & \multirow[b]{2}{*}{$\begin{array}{l}\text { Aqueous } \\
\text { Extract }\end{array}$} & \multicolumn{2}{|c|}{ Observation } \\
\hline & & & $\begin{array}{l}\text { Alcoholic } \\
\text { Extract }\end{array}$ & $\begin{array}{c}\text { Pet.ether } \\
\text { Extract }\end{array}$ \\
\hline 1 & $\begin{array}{ll}\text { Tests for sterols } \\
\begin{array}{ll}\text { 1. } & \text { Salkowski's Test } \\
\text { 2. } & \text { Libermann Burchard's Test }\end{array}\end{array}$ & $\begin{array}{l}+ \\
+\end{array}$ & $\begin{array}{l}- \\
-\end{array}$ & $\begin{array}{l}- \\
-\end{array}$ \\
\hline 2 & $\begin{array}{ll}\text { Test for glycosides } \\
\text { 1. } & \text { Baljet's Test } \\
\text { 2. } & \text { Brontrager Test }\end{array}$ & + & - & $\begin{array}{l}- \\
-\end{array}$ \\
\hline 3 & $\begin{array}{r}\text { Tests for saponins } \\
\text { 1. Foam Test }\end{array}$ & + & - & - \\
\hline 4 & $\begin{array}{c}\text { Test for carbohydrates } \\
\text { 1. Molish's Test } \\
\text { 2. Barfoed's Test } \\
\text { 3. } \text { Benedict's Test }\end{array}$ & $\begin{array}{l}+ \\
+ \\
+\end{array}$ & $\begin{array}{l}- \\
- \\
-\end{array}$ & $\begin{array}{l}- \\
- \\
-\end{array}$ \\
\hline 5 & $\begin{array}{l}\text { Tests for alkaloids } \\
\text { 1. Mayer's Test. } \\
\text { 2. Wagner's Test. } \\
\text { 3. } \\
\text { Dragendorff's Test }\end{array}$ & $\begin{array}{l}+ \\
- \\
+\end{array}$ & $\begin{array}{l}+ \\
- \\
+\end{array}$ & $\begin{array}{l}- \\
- \\
+\end{array}$ \\
\hline 6 & $\begin{array}{ll}\text { Tests for flavonoids } \\
\text { 1. } & \text { Ferric chloride Test. } \\
\text { 2. } & \text { Shinoda Test. } \\
\text { 3. } & \text { Alkaline Reagent Test. } \\
\text { 4. } & \text { Lead Acetate Test. }\end{array}$ & $\begin{array}{l}+ \\
+ \\
+ \\
+\end{array}$ & $\begin{array}{l}+ \\
+ \\
+ \\
+\end{array}$ & $\begin{array}{l}- \\
- \\
- \\
-\end{array}$ \\
\hline 7 & $\begin{array}{l}\text { Tests for tannins } \\
\text { 1. } \quad \text { Ferric chloride Test. } \\
\text { 2. } \quad \text { Gelatin Test }\end{array}$ & $\begin{array}{l}+ \\
+\end{array}$ & $\begin{array}{l}- \\
-\end{array}$ & $\begin{array}{l}- \\
-\end{array}$ \\
\hline 8 & $\begin{array}{l}\text { Test for amino acid and protein } \\
\text { 1. Biurete test }\end{array}$ & + & + & - \\
\hline
\end{tabular}

Table-5: Heavy metal analysis

\begin{tabular}{|c|c|c|c|}
\hline S.No. & $\begin{array}{c}\text { Heavy } \\
\text { metal }\end{array}$ & $\begin{array}{c}\text { Desmostachya } \\
\text { bipinnata }(\text { S1) }\end{array}$ & $\begin{array}{c}\text { Permissible } \\
\text { limit }\end{array}$ \\
\hline 1 & Lead & Not Detected & $\mathbf{1 0 p p m}$ \\
\hline 2 & Arsenic & Not Detected & 3ppm \\
\hline 3 & Cadmium & Not Detected & $\mathbf{0 . 3 p p m}$ \\
\hline 4 & Mercury & Not Detected & $\mathbf{1 p p m}$ \\
\hline
\end{tabular}

Table-6: Total bacterial count

\begin{tabular}{|l|c|l|c|}
\hline S.No. & Analysis & $\begin{array}{c}\text { Desmostachya } \\
\text { bipinnata }(\text { S1) }\end{array}$ & $\begin{array}{c}\text { Permissible } \\
\text { limit }\end{array}$ \\
\hline 1 & $\begin{array}{c}\text { Total Aerobic } \\
\text { Microbial count }\end{array}$ & $\begin{array}{l}8965 \\
\text { cfu/gm }\end{array}$ & $\begin{array}{c}100000 \\
\text { cfu/gm }\end{array}$ \\
\hline 2 & Total Yeast \& & $<10$ & 1000 \\
& Mould count & $\mathrm{cfu} / \mathrm{gm}$ & $\mathrm{cfu} / \mathrm{gm}$ \\
\hline
\end{tabular}

Table-7: Test for aflatoxins

\begin{tabular}{|l|l|l|l|}
\hline S.No. & $\begin{array}{c}\text { Test for } \\
\text { Aflatoxins }\end{array}$ & $\begin{array}{c}\text { Desmostachya } \\
\text { bipinnata }(\text { S1) }\end{array}$ & $\begin{array}{c}\text { Permissible } \\
\text { limit }\end{array}$ \\
\hline $\mathbf{1}$ & Aflatoxin B1 & Absent & $\mathbf{0 . 5 p p m}$ \\
\hline $\mathbf{2}$ & Aflatoxin B2 & Absent & $\mathbf{0 . 1 p p m}$ \\
\hline $\mathbf{3}$ & $\begin{array}{l}\text { Aflatoxin } \\
\text { G1 }\end{array}$ & Absent & $\mathbf{0 . 5 p p m}$ \\
\hline $\mathbf{4}$ & $\begin{array}{l}\text { Aflatoxin } \\
\text { G2 }\end{array}$ & Absent & $\mathbf{0 . 1 p p m}$ \\
\hline
\end{tabular}


Table-8: TLC Fingerprinting

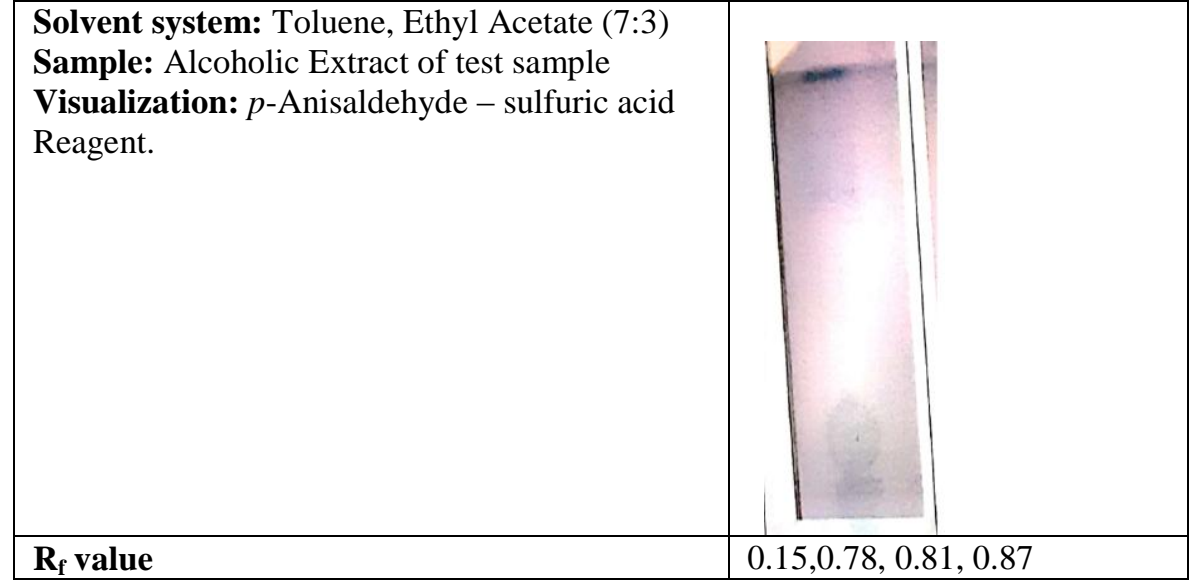

\section{REFERENCE}

1. Jitender, K., Malik., \& Saurabh, S. (2019). Botanicals Used for Anti-Hyperlipidemic Activity: A Review. Ijppr. Human, 15(3): 25.

2. Shakila, R., Meeradevi Sri, P., Arul Antony, S., \& Gopakumar, K. Antimicrobial Studies on Desmostachya bipinnata Rootstock.

3. Subramaniam, S., \& Sivasubramanian, A. (2015). Tradition to therapeutics: Sacrificial medicinal grasses Desmostachya bipinnata and Imperata cylindrica of India. Boletín Latinoamericano y del Caribe de Plantas Medicinales $y$ Aromáticas, 14(3), 156-170.

4. Mukharjee, P.K. (2002). Quality control of herbal drugs- and approach to evaluation of botanicals $31^{\text {st }}$ edition. New Delhi, Business Horizons Pharmaceuticals. Publications, 183-197.

5. Khandelwal, K.R.(1996). Practical Pharmacognosy. $\quad 3^{\text {rd }}$ edition. Pune: Nirali Prakashan, 165.

6. Malik, J. K., Manvi, F. V., Nanjware, B. R., Dwivedi, D. K., Purohit, P., \& Chouhan, S. (2010). Anti-arthritic activity of leaves of Gymnema sylvestre R. Br. leaves in rats. Der Pharmacia Lettre, 2(1), 336-341.

7. Singh. S. (2007). Effect of Rosiglitazone on Fluid and Electrolytes Transport in Jejunum and Colon of Rat In vivo:-A Possible Mechanism of Action the Pharmacist-An International Bi-annual, 2(2), 13-14.

8. Martí, M., Alonso, C., Martínez, V., Lis, M., de la Maza, A., Parra, J. L., \& Coderch, L. (2013). Cosmetotextiles with gallic acid: Skin reservoir effect. Journal of drug delivery, 2013.

9. World Health Organization. (2007). WHO guidelines for assessing quality of herbal medicines with reference to contaminants and residues. World Health Organization.

10. Zafar, J.K., Naeem, A.K., Imrana, N., Shahab, A., Nami, A. (2017). Determination of Heavy metals,Aflatoxins,Microbial loads and Pesticides residues in Sehjana(Moringa oleifera LAM) Fruits/Pods. Int. Res. J. Pharm, 8(10), 204.

11. Jitender, K.(2009). Immunomodulatory activity of Gymnema sylvestre R.Br leaves on in-vitro human neutrophils. Journal of Pharmacy Research, 2(8), 1284-1286.

12. Jitender, K. (2009). Wound healing properties of alcoholic extract of Gymnema sylvestre R.Br leaves in rats. Journal of Pharmacy Research, 2(6), 1029-1030.

13. Jitender, K., Malik. (2008). Evaluation of antiinflammatory activity of Gymnema sylvestre leaves extract in rats. International Journal of Green Pharmacy: April-June, 114-115.

14. Recent Updates On. (2019). Phytoceuticals Used In Pancreatitis Asian Journal of Medical and Health Research, 4(7), 1-13.

15. Overview on.(2017). Characteristic of isoflavones $\&$ its biological activity International Journal of Biology, Pharmacy and Allied Science, March, 6(3), 447-467.

16. Kumari, P., Dhote, V. V., \& Malik, J. K. (2016). Pathophysiological and therapeutic effect of arthritic ailments-a brief review. European Journal of Biomedical, 3(12), 179-186.

17. Singh, S., Chandel, H. S., Kushwaha, S., \& Malik, J. (2015). Evaluation of Antidiabetic Activity of Combination of Trace Elements. Chemical Science International Journal, 25-37.

18. Agarwal, T. A. R. U. N., Gupta, P. R. E. R. A. K., Asthana, S. O. M. Y. A., \& Khursheed, A. S. I. F. (2014). In silico analysis to access the antibacterial effect of thiazides on pdfs: molecular docking approach. Int J Pharm Pharm Sci, 6(6), 387-91.

19. Sharma, S., Ali, A., Ali, J., Sahni, J. K., \& Baboota, S. (2013). Rutin: therapeutic potential and recent advances in drug delivery. Expert opinion on investigational drugs, 22(8), 1063-1079.

20. Himesh, S. O. N. I., Nanda, S. A. H. U., Singhai, A. K., \& Jitender, M. A. L. I. K. (2012). Radical scavenging activities and natural indicator activity of aqueous and ethanolic extract of Rosa 
damascena. Int J Pharm Pharm Sci, 4(SUPPL 5), 581-6.

21. Himesh, S. (2012). Heavy Metals In Herbal Preparations - A Review, Int. J. Drug Res. Tech, 2(6), 430-439.

22. Himesh, S. (2012). Evaluation of Leaves of Aqueous Extract of Coleus Aromaticus and Methanolic Extract of Annona Squamosa Extracts on Cell Viability, American J. Pharm Tech Res, 2(4), 936-944.

23. Malik, J.K. (2011). Evaluation of Anxiolytic activity of Boerhaavia Diffusa Hydro-Alcoholic extract of leaves in rats International Research Journal of Pharmacy, 2(10), 90-92.

24. A Comprehensive Review on Botanical as Antiulcer Therapeutics. (2020). Prospective Avenues of Biocompatible Drug Discovery, Scholars International Journal of Tradicinal and complementary Medicine, 3(2), 27-32.

25. Amit, K. (2020). Pharmacognostical \& TLC Fingerprinting of Andrographis paniculata (Kalmegh), Saudi Journal of Medical and Pharmaceutical Sciences, 6(2).

26. Himesh, S., Jitender, M. (2020). Role of Healthy food in Prevention of Neural Tube Defects: A Review, Saudi Journal of Medical and Pharmaceutical Sciences, 6(1), 2020, 20-25.

27. Efficacy of Anti-Inflammatory Potential of Desmodium gangeticum Extracts.(2019). Advanced Research in Chemistry and Applied Science, 1(1).
28. Rutin as a Potent Inhibitor of Dihydrofolate Reductase. (2019). A Computational Design and Docking, EAS Journal of Pharmacy and Pharmacology, 1(6), 130-134.

29. Characterization of Flavonoids in Aqueous extract of Desmodium gangeticum by RP-HPLC.(2019). Global Academic Journal of Pharmacy and Drug Research,1(1): 1-4.

30. Preliminary Phytochemical Evalution and Antioxidant potential of Aerial parts of Desmodium gangeticum. (2019). Asian Journal of Medical and Health Research, 4(10), 1-11.

31. Himesh, S., Jitender, M., Abhay, Pratap, Y., \& Bhavana, Y.(2018). Evaluation of wound healing activity of methanolic extract of Annona squamosa leaves in hydrogel delivery system, American J. Pharm Tech Res, 8(3), 190-198.

32. Himesh, S., Jitender, K.M., Abhay, P. Y., \& Bhavana, Y.(2018). Characterization of rutin isolated by leaves Annona squamosa by modern analytical techniques, European Journal of Biomedical and Pharmaceutical sciences, 5(6), 484-489.

33. Evaluation of Leaves of Aqueous Extract of Coleus Aromaticus and Methanolic Extract of Annona Squamosa Extracts on Cell Viability, American J. Pharm Tech Res., 2(4), 936-944.

34. Singh, S., Chandel, H. S., Kushwaha, S., \& Malik, J. (2015). Evaluation of Antidiabetic Activity of Combination of Trace Elements. Chemical Science International Journal, 25-37. 